\title{
KNOWLEDGE OF SYNTAX VERSUS READING SKILL IN ESP
}

\author{
Aryusmar \\ English Department, Faculty of Language and Culture, Bina Nusantara University \\ Jln. Kemanggisan Ilir III No. 45, Kemanggisan/Palmerah, Jakarta Barat 11480, \\ aryusmar@yahoo.com
}

\begin{abstract}
Article clarified the relationship between knowledge of syntax and reading skill in English for specific purposes. The research was conducted at the Industrial Engineering Faculty of Trisakti University in 2002 with sample of 100 students using simple random sampling by Lottery. Data was analyzed by using simple regression test and simple correlation test. The result of the research revealed that there was a positive relationship between knowledge of syntax and reading skill in English for specific purposes. It is concluded that reading skill in English for specific purposes can be improved by increasing knowledge of syntax.
\end{abstract}

Keywords: syntax knowledge, reading skill, ESP

\begin{abstract}
ABSTRAK
Artikel menjelaskan hubungan antara pengetahuan sintaksis dan keterampilan membaca dalam bahasa Inggris untuk tujuan khusus. Penelitian dilaksanakan pada Fakultas Teknik Industri Universitas Trisakti Jakarta tahun 2002 dengan sampel sebanyak 100 mahasiswa yang dipilih dengan menggunakan sampling acak sederhana dengan undian. Data dianalisis dengan uji regresi sederhana dan uji korelasi sederhana. Hasil penelitian menunjukkan bahwa terdapat hubungan positif antara pengetahuan sintaksis dan keterampilan membaca dalam bahasa Inggris untuk tujuan khusus. Penelitian ini menyimpulkan bahwa keterampilan membaca dalam bahasa Inggris untuk tujuan khusus dapat diperbaiki melalui peningkatan pengetahuan sintaksis.
\end{abstract}

Kata kunci: sintaksis, keterampilan membaca, ESP 


\section{INTRODUCTION}

The importance of studying reading skill for non-English faculty students according to Anderson (1984: 1) is that reading skill is often important to academic studies, professional success, and personal development. This is particularly true of English as so much professional, technical and scientific literature is published in English today. Therefore, we can not deny that reading skill is very much needed by non-English students for their academic studies, professional success, and personal development. In addition, Hutchinson and Waters (1987: 75) found that a need analysis reveals that ESP learners need English in order to be able to read texts in their subject specialties.

In fact, most students fail to learn to read adequately in a foreign language. Readence, Bean, and Baldwin (1985: 3) found that thousands of students leave high school not knowing how to read at all; many more thousands depart with reading skill so inadequate that they can't hope to survive the demands of our print-bound culture.

Karlin (1984: 7) also found that many students, because they are passive readers, find that the subject matter materials are more difficult to read than those that tell a story.

The facts above show that reading skill in English for specific purposes can not be obtained easily or naturally; however, it must be achieved through a systematic program of teaching and learning process. It is the duty and responsibility of lecturers to make the teaching and learning process successful.

In an attempt to carry out the improvement of teaching and learning process for reading skill in English for specific purposes, the factors that can give significant contributions toward the improvement should be searched. Mikulecky (1990: 9) pointed out that every language has a different way of making sense of the world, learning to comprehend written text in a second or foreign language is a complex task. Therefore, searching for the factors is very important because the ignorance of the factors can influence the success of students to improve their reading skill in English for specific purposes.

Vacca and Gove (1987: 12) stated that syntactical information is provided by grammatical relationships within sentence patterns. In other words, readers use their knowledge of meaningful arrangement of words in sentences to help construct meaning from text material.

In line with the statements above, it can be identified that one important factor to be taken into account in dealing with an attempt to increase the students' reading skills in English for specific purposes is knowledge of syntax.

\section{Formulation of Problem}

In line with the background above, the problem can be formulized as follows:

Is there any relationship between the knowledge of syntax and reading skill in English for specific purposes?.

\section{Theoretical Framework}

\section{Reading Skill in English for Specific Purposes}

Vallete (1997: 166) stated that reading by definition is a language skill. Therefore, the term "skill" used in this research refers to one of the language skills that is reading skill. Cotton, Falvey, 
and Kent (2002: 159) defined skill as an ability to do something well, especially because you have learned and practiced it. On the other hand, Gardner in Sussar and Robb (1990: 1) pointed out that the term skills related to reading are better regarded as activities involving comprehension than as categories of abilities. Therefore, the term "skill" in this research emphasizes more to comprehension activities than merely to the categories of abilities.

The type of skill involving comprehension activities in this case refers to cognitive activities. Eskey (1986: 6) stated that reading is primarily a cognitive process, which means that the brain does most of the work. In addition, Harmer (1991: 190) also pointed out that reading involves an exercise, which is dominated by eyes and brain. The eyes receive messages and the brain then has to work out the significance of these messages. Therefore, the term "skill" involving comprehension activities in reading process refers to the reader's cognitive skills.

Mikulecky (1990:28) pointed out that the cognitive skills are the strategies which the reader employs in making sense of a passage. In addition, Klein, Peterson and Simington (1991: 7) stated that reading is strategic. Effective readers employ reading strategies appropriate both to the text and to the context in order to construct meaning when reading. Therefore, it can be pointed out that the term "skill" used related to reading means the strategies that are used by readers to attain the comprehension. The appropriate strategies applied by readers enable them to increase their speed and comprehension of texts. In other words, once the readers are conscious of the skills and how to use them, readers can learn to monitor their own comprehension and apply appropriate strategies as needed for making sense of a text.

The point of view above will imply that the main goal of the English for specific purposes reading program should be to enable students to apply the appropriate skills or strategies in reading.

Referring to the skills or strategies above, Ghani (1983: 48) pointed out that there are only three reading skills recognized as essential by most language instructors: scanning, skimming, and intensive reading. Therefore, it can be stated that the term "skill" related to English for specific purposes reading in this research refers to skimming, scanning, and intensive reading.

St. John (1994: 8) pointed out that skimming involves quickly finding the main ideas, usually by looking at the first and last paragraphs and the first sentences of other paragraphs; scanning is looking through the text for particular information, usually looking for the key words, dates, numbers, etc; and intensive reading is a kind of reading strategy which has to be done more carefully to comprehend detailed information. In addition, Evans and John (1998: 98) stated that skimming and scanning are useful first stages for determining which parts to read carefully.

Mikulecky (1990: 1) stated that in most cases, especially in academic settings, a reader expects a text to make sense. Gould also stated that we read to understand, to make sense of texts. Furthermore, Flood and Lapp (1981: 350) pointed out that reading is comprehension; If you have not comprehended, you have not read. Eskey (1986: 4) also stated that the language of the text is only a tool to reach the end. The end is comprehension. Therefore, it can be stated that the comprehension is the main goal of any reading activities.

Karlin (1984: 191) pointed out that a common way to view comprehension as being literal, inferential, and evaluative. When students read for literal meaning they are concerned merely with surface messages, when students read for inferential meaning they are concerned with reading between the lines, and when students read for critical meaning they may react to ideas from what writers say.

From the points of views above, in this research it can be classified that the skimming and scanning are applied at the beginning to comprehend the literal information and intensive reading is 
applied to comprehend more detailed information that can be obtained by the inferential and evaluative questions based the English for specific purposes text.

Cunningsworth (1995: 64) pointed out that in selecting the English for specific purposes text materials, we should consider the learner's needs and level of language appropriate to the students. Evans and John (1998: 46) also emphasized that one of the most important contributions to the approach to reading in English for specific purposes was the shift from text as a linguistic object (TALO) to text as a vehicle of information (TAVI). Therefore, it can be pointed out that the suitable text for ESP students in this research is a text containing not only as a linguistic object but also as a vehicle of information which aims to increase the students' reading skill in English for specific purposes related to their specialties.

Langan (1989: 308) pointed out that there are several important components of comprehension dealing with reading skill in English for specific purposes including: recognizing a subject or topic, determining the main idea, identifying key supporting points, making inferences, and understanding vocabulary in context. In addition, Evans and John (1998: 98) stated that English for specific purposes readers need to read carefully, extract meaning and the author's attitude. Author's attitude is particularly important.

In line with the statements above, it can be concluded that reading skill in English for specific purposes - in this research - is defined as: skimming to obtain literal comprehension such as recognizing the topic and determining the main idea; scanning to obtain literal comprehension such as identifying the key supporting points; and intensive reading to obtain inferential comprehension such as making inferences, and predicting vocabulary in context; and evaluative comprehension such as extracting the author's attitude based on English for specific purposes text related to Industrial Engineering.

\section{Knowledge of Syntax}

Popham (1975: 58) pointed out that the knowledge level of the cognitive taxonomy describes leaner activities that basically deal with memory or recognition.

Anderson and Krathwohl (2001: 45) stated that one dimension of knowledge is factual knowledge. It encompasses the basic elements that experts use in communicating about their academic discipline, understanding it, and organizing it systematically. If this point of view is related to the term "knowledge of syntax" used in this research, the dimension of factual knowledge is appropriate because non-English faculty students generally need only the practical knowledge in order that they can communicate, understand, and organize systematically when they find the syntactical information in the process of reading the English for specific purposes text. Anderson and Krathwohl (2001: 45) also pointed out that factual knowledge includes terminology, specific details, and elements. Meanwhile, Harmer (1994: 16) stated that knowledge refers to the knowing of/about certain things. In addition, Grondlund (1985: 515) explained that one classification of knowledge based on instructional objectives is that knowing of specific facts. Therefore, the term "knowledge" in this research can be defined as knowing the terminology, specific details, and elements of syntax.

Klein, Peterson and Simington (1991: 9) defined syntax as the grammar of sentences, clauses and phrases, how they are generated, and how they combine in systematic ways to produce the variety of sentence structures possible in a language. Trager (1972: 64) stated that syntax is understood to be concerned with words as put together in phrases and with phrases as put together in clauses and sentences. Falk (1978: 168) pointed out that the syntax of language is the set of principles, or constitutive rules, according to which words are combined into sentences in a language. 
Furthermore, Eastman (1985: 12) stated that syntax is a statement of the order of occurrence of forms in sentences. Lester (1995: 4) added that syntax refers to the system of rules that used to turn words into sentences. In addition, Devine (1987: 24) pointed out that knowledge of syntax is knowledge of the ways of words can be arranged in sentences. Therefore, syntax in this research can be defined as the rules to combine words in systematic ways to produce correct English sentences.

Davies (1971: 70) explained that the knowledge of syntax is about the knowledge of word class such as nouns and verbs. Delahunty and Garvey (1994: 420) elaborated that syntactic rules of usage cover a wide range of topics including parts of speech, verb tenses, pronoun reference, coordination and subordination, placement of modifiers, and sentence problems.

The topic "sentence problems" here refers to the five signals of syntactic structure of English as mentioned by Francis (1958: 423-424) namely word order, prosody, function words, inflections, and derivations. However, prosody is not discussed further because the research concerns with written text while the function words have been included in parts of speech. Therefore, the topics dealing with sentence problems as mentioned by Delahunty and Garvey will only discuss word order, inflections, and derivations.

In line with the statements above, it can be concluded that the term "knowledge of syntax" in this research is defined as the recognition of the terminology and functions of parts of speech, verb tenses, pronoun references, modifiers, conjunctions, word orders, inflections, and derivations to produce the correct English sentences.

\section{Relationship between Knowledge of Syntax and Reading Skill in English for Specific Purposes}

Knowledge of syntax is very important for the English for specific purposes reader especially when they have to comprehend the syntactical information available in English for specific purposes text. Syntactical information is provided by the grammatical relationships within sentence patterns available in the text. Moreover, the English for specific purposes reader also needs to read efficiently. One characteristic of reading efficiently is the ability to chunk a text into sense units, each consisting of several words and each taken in by one fixation of the eyes. In short, it can be stated that phrase reading will increase both speed and comprehension. Therefore, if someone has a good knowledge of syntax, it is predicted that he/she will be able to increase reading skill in English for specific purposes.

The term "knowledge of syntax" in this research is defined as the recognition of terminology and functions of parts of speech, verb tenses, pronoun references, modifiers, conjunctions, word orders, inflections, and derivations to produce the correct English sentences. It means that by being having good knowledge of syntax, the reader is expected not only to be able to differentiate which sentence is grammatically correct and which is not, but also to be able to chunk a text into sense of units to increase speed and comprehension. Therefore, it is expected that the knowledge of syntax in this research can improve the reader's reading skill in English for specific purposes. In line with the statements above, it is expected that there will be a positive relationship between the knowledge of syntax and reading skill in English for specific purposes. In other words, the higher the reader's knowledge of syntax, the higher the reader's reading skill in English for Specific Purposes will be.

\section{Research Hypotheses}

The research hypotheses can be formulated as follows. There is a positive relationship between knowledge of syntax and reading skill in English for specific purposes of the industrial engineering faculty student of Trisakti University. 


\section{RESEARCH METHODS}

This research used a survey method with a correlation technique. It was conducted at Industrial Engineering Faculty of Trisakti University during the odd semester of 2002/2003 academic year. Population in this research was all the students of English III subject because these students had already taken reading skill in English for specific purposes subject. The sum of the samples was 100 students selected by using simple random sampling by lottery.

The research used two kinds of instrument in the form of multiple choice objective tests including reading skill in English for specific purposes test and knowledge of syntax test. The data analysis was done by using simple regression, multiple regressions, simple correlation, and multiple correlations.

The constellation of the problems can be seen in Figure 1.

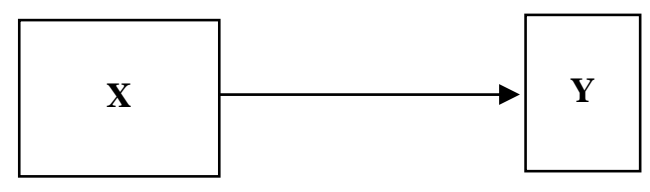

Figure 1 The Constellation of the Problems

Remarks:

X : Knowledge of Syntax

Y : Reading Skill in English for Specific Purposes

\section{RESULTS AND DISCUSSION}

\section{Data Description}

Data description can be summarized in the following table.

Table 1 The Summary Data Description

\begin{tabular}{lll}
\hline \multicolumn{1}{c}{ Statistics } & \multicolumn{1}{c}{$\mathbf{Y}$} & \multicolumn{1}{c}{$\mathbf{X}$} \\
\hline Mean & 20.70 & 38.10 \\
Median & 21 & 38 \\
Mode & 21 & 35 \\
Std. Deviation & 3.80 & 8.09 \\
Variance & 14.51 & 65.56 \\
Range & 15 & 31 \\
Minimum & 13 & 22 \\
Maximum & 28 & 53 \\
Sum & 2070 & 3810 \\
\hline
\end{tabular}




\section{Tests of Analysis Requirements for Normality}

The normality tests use the Kolmogorov-Smirnov test. The result can be summarized in the following table.

Table 2 The Summary of Normality Tests

\begin{tabular}{ccccccc}
\hline \multirow{2}{*}{ Variable } & $\mathbf{N}$ & $\boldsymbol{a}_{\max }$ & \multicolumn{2}{c}{$\boldsymbol{D}_{\text {table }}$} & \\
\cline { 5 - 6 } & & & $\boldsymbol{\alpha}=\mathbf{0 . 0 5}$ & $\boldsymbol{\alpha}=\mathbf{0 . 0 1}$ & Remarks \\
\hline $\mathrm{Y}$ & 100 & 0.081 & 0.122 & 0.152 & Normal \\
$\mathrm{X}$ & 100 & 0.077 & 0.122 & 0.152 & Normal \\
\hline
\end{tabular}

Remarks:

Y : Reading Skill in English for Specific Purposes

$\mathrm{X} \quad$ : Knowledge of Syntax

\section{Tests of Analysis Requirements for Homogeneity}

The homogeneity tests use the Bartlett test. The result of tests can be summarized in the following table.

Table 3 The Summary of Homogeneity Tests

\begin{tabular}{|c|c|c|c|c|c|}
\hline \multirow{2}{*}{$\begin{array}{l}\text { Source of } \\
\text { Variance }\end{array}$} & \multirow{2}{*}{ Df } & \multirow{2}{*}{$\chi^{2}$ observed } & \multicolumn{2}{|c|}{$\chi_{\text {table }}^{2}$} & \multirow{2}{*}{ Remarks } \\
\hline & & & $\alpha=0.05$ & $\alpha=0.01$ & \\
\hline Y on $\mathrm{X}$ & 68 & 28.24 & 88.25 & 98.03 & Homogenous \\
\hline
\end{tabular}

\section{Relationship between Knowledge of Syntax and Reading Skill in English for Specific Purposes}

Simple regression analysis $\mathrm{Y}$ on $\mathrm{X}$ has obtained the regression equation $\hat{\mathrm{Y}}=8.64+0.32 \mathrm{X}$. Then, the result of the significance and linearity test of the regression equation is described in the following table.

Table 4 The Analysis of Variance for the Significance and Linearity Tests of Regression Equation $\hat{Y}=8.64+0.32 \mathrm{X}$

\begin{tabular}{|c|c|c|c|c|c|c|}
\hline \multirow{2}{*}{$\begin{array}{l}\text { Source of } \\
\text { Variance }\end{array}$} & \multirow{2}{*}{ df } & \multirow{2}{*}{ SS } & \multirow{2}{*}{ TMS } & \multirow[b]{2}{*}{$F_{\text {observed }}$} & \multicolumn{2}{|c|}{$F_{\text {table }}$} \\
\hline & & & & & $\alpha=0.05$ & $\alpha=0.01$ \\
\hline Total & 100 & 44286 & & & & \\
\hline Regression (a) & 1 & 42849 & & & & \\
\hline Regression & 1 & 650.597 & 650.597 & $81.07 * *$ & 3.91 & 6.90 \\
\hline$(\mathrm{b} / \mathrm{a})$ & 98 & 786.403 & 8.025 & & & \\
\hline Residual & & & & & & \\
\hline Lack of Fit & 30 & 295.340 & 9.845 & $1.55^{\mathrm{ns}}$ & 1.63 & 1.99 \\
\hline Error & 68 & 431.967 & 6.352 & & & \\
\hline
\end{tabular}


Remarks:

** $\quad$ : Very significant $\left(F_{o}=81.07>F_{t}=6.90\right)$

ns $\quad:$ non significant $=$ linear $\left(F_{o}=1.55<F_{t}=1.99\right)$

df : degree of freedom

SS : : Sum of Squares

TMS : Total Mean Square

From the table above, it shows that the simple regression equation $\hat{\mathrm{Y}}=8.64+0.32 \mathrm{X}$ is very significant and regression $\mathrm{Y}$ on $\mathrm{X}$ is linear. It means that if the knowledge of syntax is increased one score, reading skill in English for specific purposes will increase 0.32 score on constant 8.64. The graphic line of regression equation can be seen in the following figure:

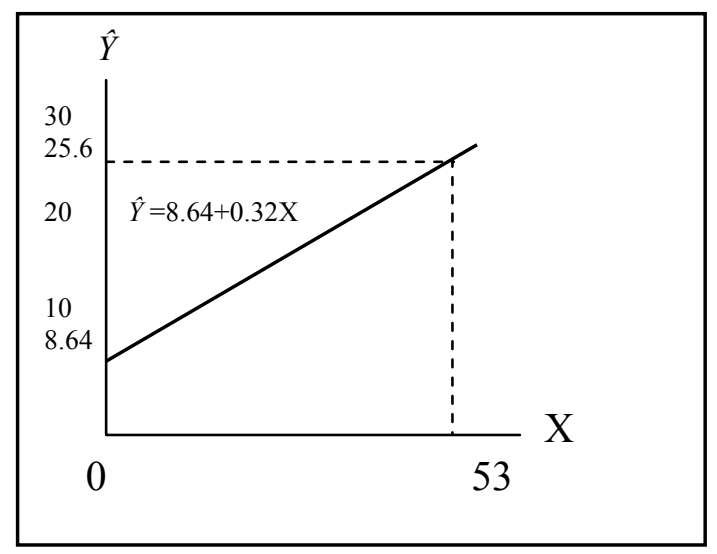

Figure 2 The graphic line of Regression Equation $\hat{Y}=8.64+0.32 X$

Furthermore, the correlation analysis between knowledge of syntax $(\mathrm{X})$ and reading skill in English for specific purposes $(Y)$ has resulted correlation coefficient $\left(r_{y}\right)=0.673$. Then, the significance test of correlation coefficient $\mathrm{X}$ between $\mathrm{Y}$ can be seen in the following table.

Table 5 The Result of Significance Test of Correlation Coefficient between X and Y

\begin{tabular}{ccccccc}
\hline \multirow{2}{n}{} & \multirow{2}{*}{$\mathbf{r}_{\mathbf{y}}$} & $\mathbf{r}_{\mathbf{y}}{ }^{2}$ & $\boldsymbol{t}_{\text {observed }}$ & \multicolumn{2}{c}{$\boldsymbol{t}_{\text {table }}$} \\
\cline { 5 - 6 } 100 & 0.673 & 45.29 & $12.11^{* *}$ & 1.66 & 2.37 \\
\hline
\end{tabular}

Remarks:

** $\quad:$ Very significant $\left(t_{\mathrm{o}}=12.11>t_{\mathrm{t}}=2.37\right)$

$r_{\mathrm{y}} \quad$ : Correlation coefficient between $\mathrm{X}$ and $\mathrm{Y}$

The result of the significance test in the table above shows the correlation coefficient between the knowledge of syntax and reading skill in English for specific purposes is very significant. Therefore, it proves there is a positive relationship between knowledge of syntax and reading skill in English for Specific Purposes. It means the higher the reader's knowledge of syntax, the higher the reading skill in English for specific purposes will be. 
The strength of correlation between knowledge of syntax and reading skill in English for Specific Purposes is stated by the coefficient of determination $\left(\mathrm{r}_{\mathrm{y}}\right)^{2}=(0.673)^{2}=0.4529$. It means that $45.29 \%$ of reading skill in English for Specific Purposes is determined by knowledge of syntax. In other words, the knowledge of syntax gives a contribution of $45.29 \%$ to reading skill in English for specific purposes.

\section{CONCLUSION}

In line with the theoretical framework and research findings above, this research concluded that reading skill in English for specific purposes could be improved through increasing the knowledge of syntax. In line with the conclusion above, the research finding implies to the theory of syntax related to reading skill as stated previously by Vacca, Vacca and Gove that syntactical information is provided by grammatical relationships within sentence patterns. In other words, readers use their knowledge of meaningful arrangement of words in sentences to help construct meaning from text material. Therefore, the research has some implications concerning with the efforts to increase the knowledge of syntax. The efforts will be described as follows.

An effort to increase the knowledge of syntax should be undertaken systematically in order to improve reading skill in English for specific purposes as: Firstly, an effort that should be aimed at introducing the terminology and functions of topics that were formulated in the definition of the knowledge of syntax in the research such as: parts of speech, verb tenses, pronoun reference, modifiers, conjunctions, word orders, inflection, and derivation. Secondly, an effort that should be aimed at giving detailed comprehension of syntactical rules either on the sentence or text level. This effort can be started by giving exercises for recognising the syntactical rules at sentence level. For non-English Faculty students, syntactical rules are still abstract at the beginning if we directly use English for specific purposes text. Then, after many exercises at sentence level, we can continue to give the exercises by using the English for specific purposes text. Finally, an effort that should be aimed at measuring the success of all activities involved in increasing the knowledge of syntax.

In line with the research findings and implications above, it can be suggested as follows: Firstly, it is suggested for the lecturer of reading skill in English for specific purposes: to systematically improve the teaching program of reading skill in English for specific purposes which is aimed at increasing in the student's reading strategy consisting of skimming, scanning and intensive reading in order to be able to obtain the literal comprehension such as: recognising the topic, determining the main idea, and identifying the supporting details; inferential comprehension such as predicting the vocabulary in context and making inference; and evaluative comprehension such as extracting the author attitude efficiently and effectively; and to conduct an integrated teaching program aimed at increasing the knowledge of syntax focusing on recognising the terminology and functions of parts of speech, verb tenses, pronoun reference, modifiers, conjunctions, word orders, inflections, and derivations. Secondly, it is suggested for the student: to use the strategies in any kinds of reading activities; to become accustomed to reading any kind of English text to practice using English in communication; to think logically in doing anything; to follow any kinds of activity that can increase English skill such as taking an English course. Finally, it is suggested for the academic researcher to conduct the relevant research on reading skill in English for Specific Purposes more deeply by using another variables and different approaches. 


\section{REFERENCES}

Anderson, J. C. (1984). Reading in foreign language: A reading problem or a language problem? in J. Charles Anderson and A. H. Urquhart (ed.), Reading in a foreign language. London: Longman Group Limited.

Anderson, L. W., and Krathwohl, D. R (ed). (2001). Taxonomy for learning, teaching, and assessing abridged edition, New York: Addison Wesles Longman, Inc.

Cotton, D., et al. (2000). Market leader: Course book intermediate business English, England: Pearson Education Limited.

Cunningsworth, A. (1995). Choosing your course book, Great Britain: Heinemann.

Davies, F. (1995). Introduction reading, England: Penguin Books Ltd.

Delahunty, G. P., and James J. G. (1994). Language, grammar, and communication, Singapore: McGraw-Hill Book Co.

Devine, T. G. (1987). Teaching study skill, Boston: Allyn and Bacon, Inc.

Eastman, C. (1985). Aspects of language and culture, USA: Chandler \& Sharp Publishers, Inc.

Eskey, D. E. (1986). "Teaching Second Language Reading for Academic Purposes" in Fraida Dubin, David E. Eskey and William Grabe (ed.), Theoretical Foundations, USA: Addison-Wesley Publishing Company.

Evans, T. D., and St. John, Maggie Jo. (1998). Development in English for specific purposes, United Kingdom: Cambridge University Press.

Falk, J. S. (1978). Linguistics and language: A survey of basic concepts and implications, USA: John Wiley \& Sons, Inc.

Flood, J., and Lapp, D. (1981). Language reading instruction for the young child, USA: Macmillan Publishing Co., Inc.

Francis, W. N. (1958). The structure of American English, New York: The Ronald Press Company.

Ghani, S. A. (1993). "English for specific purposes reading: Some implications for the design of materials" in selections from: English Teaching Forum, English for specific purposes, Jakarta: USIS Regional English Programs Office.

Harmer, J. (1991). The practice of English language teaching, London: Longman Group UK Limited.

Hutchinson, T., and Waters, A. (1987). English for specific purposes, USA: Cambridge University Press.

Karlin, R. (1984). Teaching reading in high school: Improving reading in the content areas, New York: Harper \& Row, Publishers, Inc. 
Klein, M. L., Peterson, S., and Simington, L. (1991). Teaching reading in the elementary grades, USA: Allyn and Bacon.

Langan, J. (1989). College writing skill with reading, USA: McGraw-Hill, Inc.

Lester, P. M. (1985). "Syntactic theory of visual communication" in Visual communication images with massages, California. Retrieved from http://Com-faculty. Fullerton.edu/ lester /writings/viscomtheory.html.

Mikulecky, B. S (1990). A short course in teaching reading skill, Addison-Wesley Publishing Company, Inc.

Popham, W. J. (1975). Educational evaluation, USA: Prentice Hall, Inc.

Readence, J. E., Bean, T. W., and Baldwin, R. S. (1985). Content area reading: An integrated approach, California: Kendall /Hunt Publishing Company.

Sussar and Robb. (1990). "EFL Extensive reading instruction: Research and procedure" in Sussrobb.net. JALT Journal. Retrieved from http: //www2 kyoto-su.ac.jp/-trobb /Suss robb. html.

St. John, and Jo, M (1994). Professional reading skill series: Advertising and the promotion industry, UK: Prentice Hall International Ltd.

Trager, L. G. (1972). Language and languages, USA: Chandler Publishing Company.

Vacca, J. A. L., Vacca, R. T., and Gove, M. K. (1987). Reading and learning to read, Boston: Scott, Foresman and Company. 